\title{
複数の分野から構成されるテストにおけるIRTを用いた項目評価法 臨地実習適正化のための看護系大学共用試験の項目バンク構築
}

\author{
光 永 悠 彦*, 柳 井 晴 夫, 西 川 浩 昭** \\ 佐 伯 圭一郎***, 亀 井智 子†, 松 谷 美和子† \\ 奥裕 美 ${ }^{\dagger}$ 村木 英 治咀
}

An attempt to evaluate the method to construct multiple domains of IRT-based scales

- For the purpose of building item bank for a common achievement test for nursing colleges

\begin{abstract}
Haruhiko Mitsunaga*, Haruo Yanai, Hiroaki Nishikawa**, Kei'ichiro Saiki ${ }^{* * *}$, Tomoko Kamei ${ }^{\dagger}$, Miwako Matsutani ${ }^{\dagger}$, Hiromi OKU ${ }^{\dagger}$ and Eiji Muraki ${ }^{\dagger \dagger}$
\end{abstract}

\begin{abstract}
Background: As Japanese nursing colleges increasingly require common criteria for assessing practical nursing ability prior to entering clinical hospital practice, it is important to construct a test item bank that can facilitate the evaluation of multiple domains. However, ordinal IRT models, such as the 2 parameter logistic model (2PL), operate under the assumption of unidimensionality, preventing application to comprehensive testing of multiple domains. Method: We conducted a computer-based test with items from 20 domains, classified into three areas: (1) basic medicine, (2) basic nursing, and (3) clinical nursing. About 780 students answered items, which were applied to common-item design and calibrated item parameters using two strategies; the first strategy assumed one-factor model for each area, the second strategy assumed unidimensionality by domain. Conclusion: For constructing an item bank, estimating item parameters by domain results in larger test information and more appropriate parameter estimates than estimating parameters by area.
\end{abstract}

Key words: item response theory, unidimensionality, item bank, practical nursing. キーワード：項目反応理論，一次元性，項目バンク，看護系大学共用試験

\section{*人事院人材局試験専門官室}

(Office of Examination Officers, National Personnel Authority)

著者連絡先：テ 100-8913 東京都千代田区霞が関 1-2-3

Tel : 03-3581-5311（内線 2398)

E-mail : h-mitsu@bk.iij4u.or.jp, mitsunagahar-3xg3@jinji.go.jp

**静岡県立大学看護学部

(University of Shizuoka, School of Nursing)

***大分県立看護科学大学

(Oita University of Nursing and Health Sciences) †聖路加看護大学

(St. Luke's College of Nursing)

†東北大学大学院教育情報学研究科

(Tohoku University Graduate School of Educational

\section{1. 問題と目的}

\section{1. 医療系共用試験の現状}

医療に携わる人材を育成する場面に抒いて，臨床・ 実務場面で一定の水準以上の質をもって患者に接する 技術を身につけさせるために，これまでさまざまな統 一的カリキュラムが示されてきた。たとえば医学科に おいて「モデル・コア・カリキュラム」と呼ぶ一連の 臨床実習前に㧍ける教育方針が挙げられる。このよう な統一的カリキュラムは, すでに歯学科, 薬学科にお いても策定されており, それらのカリキュラムは教育

Informatics Research Division) 
現場で共有が図られ，医療現場における質の確保に貢 献しているといえる.

また, これらのカリキュラムに基づく教育を通じ, 学 生がどの程度の学力, すなわち臨床・実務場面で身に つけておくべき知識抄よび技能を備えているかを測定 するためのテストも開発されてきた。医学科において は, 6 年のカリキュラム年度のうちの 5 年次以降, 臨 床実習を行う関係から，4年次終了時点に扔いて全医 学科学生対象の「共用試験」を実施している (医療系大 学間共用試験実施評価機構, 2012).

しかしながら, 看護系の大学においては, 共用試験 にあたるような，臨地実習前に行われる統一的な試験 がなく，またモデル・コア・カリキュラムも策定され ていない，近年の社会情勢に扔いて，看護に携わる人 材を育成することがますます重要になる中，医療に携 わる者を育成するうえで, 看護の質を確保することは 必須であるといえる。このような現状を踏まえ, 近年, いくつかの看護系大学を中心に, 看護系大学における モデル・コア・カリキュラムの策定と CBT (computer based test）の試みが行われるようになった。

\section{2. 看護系 CBT の役割および基本設計}

看護系 $\mathrm{CBT}$ の担う役割は, 看護系大学に扔ける 3 年次以降のカリキュラムにおいて臨地実習を行う前に, 必要十分な知識及び適性を備えているかどうかを判断 することにある。その際, 学生がどの大学に在籍して いるかに関わらず，統一された基準によってスコアが 表示されることが必要であり, また, カリキュラム年 度が異なる学生間で共通の尺度によってスコアが表示 されている必要がある，以上の前提より，本論で述べ る看護系 $\mathrm{CBT}$ 本試験は, 臨地実習前の学生全員に対 し, その適性を判断するための道具でなければならな い.また, 年度間共通のモデル・コア・カリキュラム を日本の看護系大学に扔いて統一し, それに準拠した 試験とすることで, 年度間㧍よび大学間に共通な基準 を定義することが可能である.

医学系や歯学系, 薬学系の CBT においては, 多数の 項目（以下，設問の意味で「項目」(item）という語を 用いる）を事前に作成し，それらを「トライアル試験」 として本試験と同等の学力を持つと想定される受験者 群に提示し，ここで得られた正誤反応から IRT（item response theory）に基づく項目パラメ夕を推定すると いう手順を行っている。このようにして本試験で提示 される項目の信頼性を検証しつつ, トライアル試験の
受験者と比較可能な尺度によって, 受験した年度にか かわらず共通の成績が表示できる.

看護系大学をまたいで共通の尺度による成績の表示 に関しては, 医学系や歯学系, 薬学系の CBT と同様, IRT に基づく各項目のパラメ夕を CBT 本試験実施前 に推定しておき, CBT 本試験においては項目パラメ夕 が既知の項目群を提示するという手続きを踏む。これ により, 出題される項目の難易度や項目七ットの信頼 性がどの受験者に対しても一定となるような試験とす ることが可能となる。しかし，この方法をとる前提と して, 多数の項目に対し, 規準となる集団上での項目 の困難度などの項目パラメ夕をあらかじめ推定し, 項 目の内容とともに記録する項目バンクの作成が必要で ある。

柳井ほか (2012) は, 以上の背景を踏まえ, 臨地実習 前の看護系大学学生に課す $\mathrm{CBT}$ の基礎的研究を行っ ている.この研究では臨地実習前の学生に必要な知識 として「基礎医学科目」「看護専門科目」を想定し, こ れらを測定する全 18 分野からなる CBT を実施した. しかし, CBT の実用化に向けての課題として, 柳井ほ か (2012) では,「CBT 試験の妥当性及び信頼性のさ らなる情報の蓄積」が検討すべき「急務の課題」であ ると述べている (p.9). 柳井ほか (2012) の研究で用い られた項目のうち, 「老年看護学」に属する分野につい ては, 亀井・西川・柳井 (2013) に扔いてその項目の性 質について議論されているが，1 分野のみにおける質 的考察にとどまっており, 他の分野との関連は検討さ れていない. 本研究では, 実デー夕を用いて項目バン クを作成する手続きとして，分野の違いを考慮に入れ たモデルをどのように適用すべきかを, 実際の CBT 実施により得たデー夕を用いて検討する（なお，本研 究においては, 6.1 節に示す理由により, 学生に「基礎 学力科目」も課して抢り, 合わせて 20 分野に扔ける CBT の結果について述べる).

\section{3. 複数の分野からなるテストの一次元性}

以上述べた 3 科目の尺度化に際しては, それぞれの 科目に含まれる広範囲にわたる下位尺度, すなわち複 数の「分野」の存在が, IRT に基づく尺度化を行う上 での前提の一つである「尺度の一次元性」にどの程度 影響があるか検討する必要があるといえる。看護専門 科目は柳井ほか (2012) において 12 分野が挙げられて おり，各分野に別個に一次元性を仮定した尺度化をす ることによって, IRT の前提である一次元性がより明 
確な形で表現可能である（12 分野の内容については， 2.1 節に示した表 1 と同一)。しかし，柳井ほか (2012) においてはそれら 12 分野の正誤反応から得られた相関 行列に対し主成分分析を行った結果，大きな第一主成 分 (主成分の寄与が $30 \%$ 以上 ${ }^{1)}$ ) を得たことから, IRT による分析も 12 分野すべてを併合した形で行ってい る。この場合，それぞれの分野の「内」で同一の概念 を測定しているテストを複数併合したデー夕，すなわ ちデータが一次元であるとは仮定できないデー夕に, 併合後のテストが一次元であることを仮定した分析を 行っていることとなり，推定が不安定となることが指 摘できる。また，アンカー項目（冊子間に共通に出現 する項目）による「共通項目デザイン」を用いた等化 場面においては, 得られた項目パラメ夕, 特に識別力 の值が過小に推定される可能性が指摘できる（詳しい 議論は光永・前川 (2013) を参照のこと). また, 佐藤・ 柴山 (2011) は, いくつかの分野から構成されるような テストの尺度化場面について，分野ごとに分割して尺 度化した場合，分野をまとめて尺度化した場合に比べ て, 能力值 $\theta$ の標準誤差が小さくなることをブートス トラップ法によるシミュレーション研究によって示し た。したがって, 本研究に拉いても, 分野ごとに別々 に尺度化する方法をとった場合，そこから得られた $\theta$ の標準誤差が，12 分野すべてを併合して尺度化した $\theta$ と比較して小さくなることが期待される。しかし，こ のような尺度化の方法の結果, 柳井ほか (2012) で得 られた項目パラメ夕と著しく傾向が異なる推定結果と なる可能性も否定できない。また，本研究では多次元 IRT (Multidimensional IRT; MIRT) モデルを適用 せず，一次元を仮定した IRT モデルを適用した場合を 取り上げる (理由は 6.2 節を参照).

\section{4. 本論の目的}

本論では, 複数の下位尺度 (本研究における「分野」) からなる看護系大学共用 $\mathrm{CBT}$ 本試験の項目バンクに 使用することを最終目的とし, 複数の分野にわたる多 数の項目の性質を知るために行ったトライアル試験の 分析を通じて，テストの実践場面に打いて (a) 分野ご との尺度化をし, 適性があるか否かの判断には合成得 点を用いる (以下, 「分野別の推定」と表記), (b) 傾向 の似た複数の分野をまとめて「科目」とし，科目単位で

1) Reckase (1979) によると四分位相関行列における第 1 主成分の寄与率が $20 \%$ 以上であることが一次元性を 満たす条件の一つであるとされる。
尺度化し, 得られた $\theta$ の尺度で適性の有無を判断する (以下,「科目単位の推定」と表記), の 2 種の方法を比 較し, 得られた項目パラメ夕, テスト情報量曲線（Test information curve; TIC) および $\theta$ (合成得点) がどの 程度異なるかを検討することを目的とする。また，テ ストの一次元性の指標として主成分分析に基づく方法 を用い，一次元性が高い分野とそうでない分野で項目 パラメタや $\theta$ の推定值の傾向が異なるかを検討する. (a) および (b) の方法で項目パラメ夕や $\theta$ の值が同じ であれば，佐藤・柴山 (2011) で指摘されるように, (a) の方法を使うことで $\theta$ の標準誤差を小さくすることが 可能である. 本研究ではトライアル試験のサンプルに おける $\theta$ の上で標準誤差を小さくすることに対応する が, 項目バンクを用いて行われる本試験においても (a) の方法による尺度化を行うようにすれば，本試験受験 者で推定される $\theta$ についても標準誤差を小さくするこ とが可能であるので, 項目バンク構築時における推定 方法の差異を検討することが必要であると考える。

\section{2. 看護 CBT トライアルの概要および方法}

\section{1. 出題科目及び分野, 出題項目の内容}

本研究の CBT では柳井ほか (2012) と同様に, 表 1 に示す「看護専門 I 科目」「看護専門 II 科目」「基礎医 学科目」の計 18 分野をモデル・コア・カリキュラムに 従い用意し,「看護専門 I 科目」は看護学において基礎 的とされる領域であり，「看護専門 II 科目」は応用領 域に属すると定義した。 また, 「基礎学力科目」として 表 1 に示す 2 分野を設け, 出題した.

出題項目は柳井ほか (2012) で出題した内容を, 文言 の不備や不完全な状況設定を是正した上で再出題した。

表 1. 看護系 CBT トライアルで出題した分野

\begin{tabular}{|c|c|}
\hline 科目名 & 分野名 \\
\hline 看護専門 I & $\begin{array}{l}\text { 公衆衛生学, 基礎看護学, 看護教育学, } \\
\text { 看護管理学, 地域看護学, 在宅看護学, } \\
\text { 生命倫理学 }\end{array}$ \\
\hline 看護専門 II & $\begin{array}{l}\text { 成人看護学, 老年看護学, 精神看護学, } \\
\text { 小児看護学, 母性看護学 }\end{array}$ \\
\hline 基礎医学 & $\begin{array}{l}\text { 生理学, 生化学, 解剖学, } \\
\text { 病理学, 微生物学, 薬理学 }\end{array}$ \\
\hline 基礎学力 & 読解力, 推理 · 分析力 \\
\hline
\end{tabular}


本 CBT は看護系大学の臨地実習前の学生（通常 3 年 次）を対象としており，柳井 (2012) とは異なる年度に 行っているため, 同一受験者が柳井 (2012) と本 CBT を両方受験する可能性は極めて低い.

\section{2. 分野ごとの試験デザイン}

トライアル試験の目的は, 多数の項目パラメタ未知 の項目に対し，規準集団上での項目パラメ夕を推定す ることにある。しかし，一般的には多数の項目に対し てパラメ夕を推定するためには，一人の受験者が多数 の項目を解かねばならず，受験者に対して負担が大き くなるという点で現実的でない，例えば，500 問の項 目に対してパラメ夕を推定するためには，一つの受験 者グループに 500 問を解かせるのではなく，10のグ ループに対し，50 項目のユニーク項目と 10 項目のア ンカー項目をもった計 60 項目からなる 10 種類の冊子 をランダムに割り当て，等化を行うことによって，500 項目に対する全グループ共通の尺度を構成することが 可能である。このようなテス卜実施法を「重複テスト 分冊法」と呼ぶ (日本テス卜学会, 2010, p.45).

一般に, 多数の項目について項目パラメ夕を推定す る場合, 受験者をランダムにいくつかのグループに分 け，それぞれのグループに拈いて能力が等質であると いう仮定の下, 各グループに内容の異なる項目セットを 提示することで，受験者を 1 グループとした場合より も多数の項目に対して項目パラメ夕が推定できる。し かし, 実際にはグループの等質性をテスト前に仮定す ることはせず，アンカー項目を用いたテスト冊子分冊 法による試験デザインを採用し, 全ての受験者グルー プに共通の尺度上で各グループの能力值 $\theta$ および項目 パラメタを推定することが一般的手法として広く行わ れている。例えば, 国立大学法人東北大学 (2011) にお いては, 全国規模の学力調査において重複テスト分冊 法を用いたテストを実施しており，IRT に基づく等化 の手法によって多数の項目に対する項目パラメ夕を推 定している.

デザインとしては，図 1 に示すように，隣接する冊 子にアンカー項目を含め, アンカー項目の延ベ総数を 多くする方法と, 図 2 に示すような複数の冊子に共通 したアンカー項目を含めるようにする方法とがある. 前者（図 1）に示すデザインを「ユニークアンカーデザ イン」, 後者（図 2) に示すデザインを「共通アンカー デザイン」と呼ぶことにする。

$$
\text { ユニークアンカーデザインでは (1) アンカー項目と }
$$

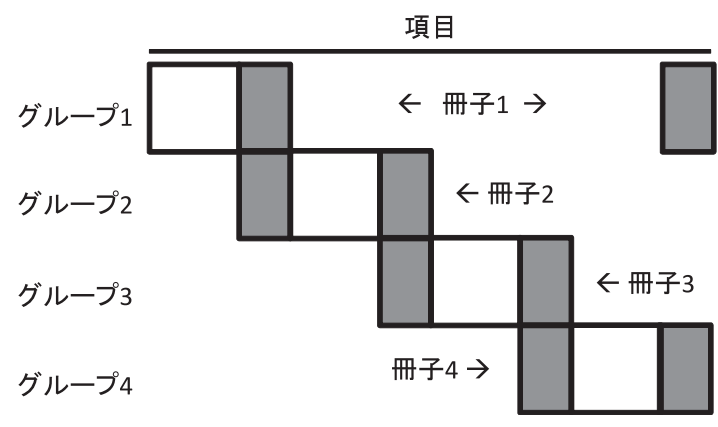

図 1. アンカー項目を冊子間で別にするデザイン

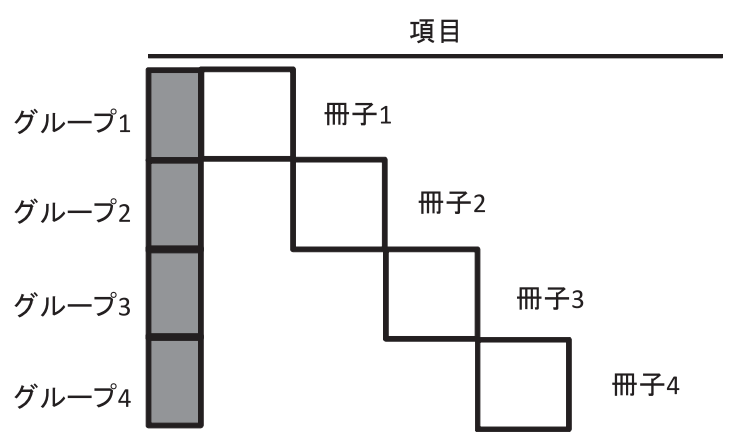

図 2. アンカー項目を冊子間で共通とするデザイン

するにふさわしいような高い識別力の項目が多数存在 する場合に適用可能である，(2) アンカー項目の数が 共通アンカーデザインに比べて多いために, 等化済み 項目パラメ夕が安定して推定可能である, といった特 徵がある。それに対して, 共通アンカーデザインでは (1) アンカー項目として使用可能な高い識別力を持っ た項目が少ない場合に適用する，(2) アンカー項目が工 ニークアンカーデザインに比べて限られるため, 仮に 識別力の低い項目をアンカー項目とした場合, 等化が 不安定となる可能性がある，といった点が特徵である.

本研究においては,「精神看護学」「小児看護学」「母 性看護学」の 3 分野に抏いて, アンカー項目に適した 項目が少なかったため, 共通アンカーデザインによる 等化を行った。また，「基礎学力」科目においては，2 分野ともに，どのグループに対しても同一の項目を提 示した（全項目をアンカー項目の扱いとした）.

\section{3. 項目数および時間割}

受験者の疲労を少なくする目的で，テスト全体を 4 つのブロックに分け，それぞれ「1 時間目」から「4 時 
表 2. 本研究で出題した項目数. $T$ は受験者 1 人当たりに 提示される項目数（テスト冊子 1 冊に含まれる項目 数), $J_{a}$ はテスト冊子に含まれるアンカー項目の数, $J_{u}$ はテスト冊子に含まれるユニーク項目の数， $A$ は 本研究のデザインによって項目パラメタが推定され る総項目数 (4 冊のテスト冊子に出現する総項目数) をそれぞれ示す

\begin{tabular}{|c|c|c|c|c|c|c|}
\hline ブロック & 科目 & 分野 & $T$ & $J_{a}$ & $J_{u}$ & $A$ \\
\hline \multirow[t]{5}{*}{1} & 看護専門 I & 公衆衛生学 & 9 & 6 & 3 & 24 \\
\hline & & 基礎看護学 & 18 & 10 & 8 & 52 \\
\hline & & 看護教育学 & 9 & 6 & 3 & 24 \\
\hline & & 看護管理学 & 12 & 6 & 6 & 36 \\
\hline & & 生命倫理学 & 12 & 6 & 6 & 36 \\
\hline \multirow[t]{4}{*}{2} & 看護専門 I & 地域看護学 & 14 & 6 & 8 & 44 \\
\hline & & 在宅看護学 & 14 & 6 & 8 & 44 \\
\hline & 看護専門 II & 老年看護学 & 15 & 6 & 9 & 48 \\
\hline & & 精神看護学 & 17 & 5 & 12 & 53 \\
\hline \multirow[t]{3}{*}{3} & 看護専門 II & 成人看護学 & 26 & 10 & 16 & 84 \\
\hline & & 小児看護学 & 17 & 5 & 12 & 53 \\
\hline & & 母性看護学 & 17 & 5 & 12 & 53 \\
\hline \multirow[t]{8}{*}{4} & 基礎医学 & 生理学 & 9 & 6 & 3 & 24 \\
\hline & & 生化学 & 8 & 6 & 2 & 20 \\
\hline & & 解剖学 & 7 & 6 & 1 & 16 \\
\hline & & 病理学 & 8 & 6 & 2 & 20 \\
\hline & & 微生物学 & 9 & 6 & 3 & 24 \\
\hline & & 薬理学 & 9 & 6 & 3 & 24 \\
\hline & 基礎学力 & 読解力 & 8 & 8 & 0 & 8 \\
\hline & & 推理 - 分析力 & 7 & 7 & 0 & 7 \\
\hline
\end{tabular}

間目」とした。それぞれのブロックにおいて，制限時 間を 45 分とし，ブロック間に 10 分の休䟤時間をとっ た。試験時間及び休憩時間の合計は 3 時間半であった。

各ブロックに, 20 分野の問題文を表 2 に示す項目数 だけ提示した。ここで，グループ数を $g$ ，テスト冊子 1 冊に含まれるアンカー項目の数を $J_{a}$, ユニーク項目 の数を $J_{u}$ とすると, 受験者 1 人当たりに出題される 項目数は $T=J_{a}+J_{u}$ となる. また, 最終的に項目パ ラメタが推定される項目数 $A$ は, ユニークアンカーデ ザインを用いた分野については

$$
A=g \cdot J_{u}+2 J_{a}
$$

の関係がある。また，共通アンカーデザインにおいては

$$
A=g \cdot J_{u}+J_{a}
$$

となる。

\section{4. 受験者および CBT 実施大学}

看護系のカリキュラムを持つ 22 の大学に対し, 各 大学内のカリキュラムに看護 $\mathrm{CBT}$ トライアルを含め るよう依頼した。 その上で, 在籍する看護系学部学生 の希望者に対し，原則無報酬で CBT を受験するよう 大学に対し依頼した。

受験者は，ランダムに 4 つのグループに分かれるよ うにし，それぞれに 4 種類のテスト冊子に対応する項 目群を提示した。 4 種類のテスト冊子にはアンカー項 目が含まれているので，後述する等化手続きによって， 4 つのグループにおける受験者の成績が共通の尺度で 表示できるようにした. 4 グループの人数は, 均等と なるように配慮した。

\subsection{CBT 実施方法および問題形式}

全 4 ブロックの問題項目について, 各大学に設置さ れたパソコン画面上に項目を提示し, 受験者に解答さ せた（システムの詳細は佐伯・品川・西川・柳井 (2013) を参照). 各項目に対し, 解答制限時間を設け, 制限 時間内に反応が記録されない場合は無回答として記録 した。

項目はすべて 5 者択一の多肢選択形式であり，原則 として一つの問題文に対して一つの設問がある形式と した。ただし，一部の項目は一つの問題文に対して複数 の設問がある形式の項目も含まれる。その場合であっ ても，一つ一つの項目で問う内容は互いに独立なよう に配慮した。

\section{6. 適用した IRT モデル}

IRT による分析は, 式 (3) に示す 2 パラメタ・ロジ スティックモデル (Lord \& Novick, 1968) を用いて 行った.

$$
P_{j}\left(\theta \mid a_{j}, b_{j}\right)=\frac{1}{1+\exp \left(-1.7 a_{j}\left(\theta-b_{j}\right)\right)}
$$

アンカー項目を用いた等化の方法として, 個別推定 (separate calibration), 同時推定 (concurrent calibration), それに項目パラメタ固定法 (Fixed Common Item Parameter; FCIP) という 3 通りの方法が ある(Hanson \& Béguin, 2002; Arai \& Mayekawa, 2011). 個別推定では，ユニーク項目が異なる，すなわ ち異なる問題冊子を提示された受験者ごとに別々に項 
目パラメタを推定し，アンカー項目の項目パラメタを 手掛かりに各比較可能な尺度に等化する方法である。 一方，同時推定では，ある受験者 $i$ が項目 $j$ に正答した 場合は 1 , 非正答の場合は 0 となるような行列 $\boldsymbol{u}=u_{i j}$ から各項目 $j$ に対する項目パラメ夕を一括して推定す る方法で，受験していない項目に対する反応は欠測と して扱う。項目パラメ夕固定法は, 項目バンク上の項 目パラメタが既知の場合に用いる等化法であるので, 本論で扱うような 4 グループに共通の尺度を構成する ための等化法としては, 個別推定と同時推定のいずれ かが挙げられる，個別推定に扔いては，測定されてい る概念において尺度の一次元性が仮定されないデー夕 に対して適用した場合，推定された識別力の值を過大 に評価する場合が想定される (光永・前川, 2012)こと や，1グループに含まれる受験者の人数が少ない場合 （正確には，正誤反応のバリエーションが少ない場合) に推定が不安定になることが予想されるため, 本論に おいては「分野別の推定」拉よび「科目単位の推定」 のいずれの場合においても, 同時推定を行うこととし た. 項目パラメタ推定および能力值推定は, いずれも BILOG-MG3 (Zimowski, Muraki, Mislevy \& Bock, 2003)を用いた.

同時推定については, 久測のあるデータ行列を用い て分析することになるが， 久測状況を示す $\boldsymbol{d}=d_{i j}$ と いうデザイン行列（1 ならば項目 $j に i$ 番目の受験者が 回答している，0ならば回答していない）を用いて，龙 度の計算に用いる「 $\theta$ を与えたときの項目反応の分布」 について式 (4)の形とすることにより, 久測のあるデー 夕を用いた IRT のパラメタ推定を行っている (前川, 1991, pp.101-102). 本論においては, BILOG-MGの not-presented key を指定することで, 欠測データの 分析を行った。

$$
\begin{aligned}
& f(\boldsymbol{u} \mid \theta, \boldsymbol{d})= \\
& \prod_{j} P_{j}\left(\theta \mid a_{j}, b_{j}\right)^{d_{i j} u_{i j}}\left(1-P_{j}\left(\theta \mid a_{j}, b_{j}\right)\right)^{d_{i j}\left(1-u_{i j}\right)}
\end{aligned}
$$

\section{7. 分野ごとの $\theta$ から合成得点を算出する方法}

「分野別の推定」の場合, $\theta$ に関しても受験者 1 人に ついて分野の数だけ推定される. 一方,「科目単位の推 定」の場合に得られる $\theta$ の推定值は, グループをまたい で $\theta \sim \mathrm{N}(0,1)$ となるように標準化された得点とするこ とによって, 項目バンクに入れる際に「トライアル試験 の受験者の能力が正規分布に従う」ということを表現で
き, 今後行われる本試験の「参照先グループ」(reference group）とする場合に都合がよい. $\theta_{i k}$ を, $i$ 番目の受 験者に扔ける $k$ 番目の科目の能力值 $(k=1,2, \ldots, K)$ とおくと, $K$ 個の分野から得られた能力值 $\theta_{i k}$ の合成 得点 $\theta_{c}(i)$ は平均 0 , 標準偏差 1 となるように正規化 された形とするのが解釈に好都合である。そのために は, まず $K$ 個の分野より合成得点の平均㧍よび標準偏 差の公式を用いて, $i$ 人の受験者に扮ける分野の合成 得点の平均 $\mu\left(\theta_{c}\right)$ および分散 $\sigma^{2}\left(\theta_{c}\right)$ を

$$
\begin{aligned}
& \mu\left(\theta_{c}\right)=\sum_{k=1}^{K} \mu\left(\theta_{k}\right) \\
& \sigma\left(\theta_{c}\right)=\sum_{k=1}^{K} \sigma^{2}\left(\theta_{k}\right)+2 \sum_{\substack{k=1 \\
k<k^{\prime}}}^{K-1} \sum_{\substack{k^{\prime}=2 \\
K}}^{K} \sigma\left(\theta_{k}, \theta_{k^{\prime}}\right)
\end{aligned}
$$

と求める.ここで $\mu\left(\theta_{k}\right)$ は $k$ 番目の分野に扮ける $\theta$ の 平均を表す.また $\sigma\left(\theta_{k}, \theta_{k^{\prime}}\right)$ は分野 $k$ と $k^{\prime}$ の共分散 を示す. 次に $\theta_{c}(i)$ の平均が 0 , 標準偏差 1 となるよ うに, 各受験者 $i$ について合成得点

$$
\theta_{c}(i)=\left(\sum_{k=1}^{K} \theta_{i k}-\mu\left(\theta_{c}\right)\right) / \sigma\left(\theta_{c}\right)
$$

を求める.

$$
\text { 3. 結果 }
$$

\section{1. 受験者人数}

各大学に対する CBT の結果, 22 大学より 785 人の 解答が得られた。基礎医学㧍よび基礎学力科目に関し ては 4 時間目に出席していた者全員を有効なデータと して扱った。ただし，4 時間目の基礎学力科目のみ久 席した受験者 1 名については, 基礎医学科目について は有効なデータとした。看護専門 I および II 科目につ いては, $n$ 時間目に出席した受験者については $n$ 時間 目に出題した全分野について有効なデータとした（当 該時間割で 1 分野のみ回答した場合, 他の分野は久測 とみなした)。

表 3 に科目別㧍よび 4 グループ別の受験者数を記し た. 表 3 で記した数は, 各科目において, すべての分 野に解答した人数である.

\section{2. 素点に基づく分析結果}

\subsection{1. 平均正答率}

有効なデー夕を用いて, 分野別に平均正答率を算出 
表 3. 有効回答数. 科目別, グループ別に記した.「全体人 数」は, 当該グループに割り当てられた受験者の総 数を示す

\begin{tabular}{lcccc} 
& \multicolumn{4}{c}{ グループ } \\
\hline & 1 & 2 & 3 & 4 \\
\hline 全体人数 & 195 & 198 & 199 & 193 \\
\hline 基礎医学 & 193 & 198 & 199 & 192 \\
看護専門 I & 194 & 197 & 198 & 193 \\
看護専門 II & 194 & 198 & 199 & 193 \\
基礎学力 & 193 & 197 & 199 & 192 \\
\hline
\end{tabular}

した結果を図 3 (基礎医学科目), 図 4 (看護専門 I 科 目), 図 5 (看護専門 II 科目) および図 6 (基礎学力科 目）に示した。基礎医学科目では，グループ間で異なる 平均正答率が見られた。特に, 生理学や解剖学におい て特定のグループのみ他のグループに比べて平均正答 率が 0.1 以上上回っており, グループ間で能力が等質 であると仮定するのが難しい結果であった。また, 看 護専門科目に扮いても, 公衆衛生学や看護管理学, 成人 看護学において, 特定のグループのみに高い（または 低い) 平均正答率が見られた。これらの結果から, IRT による分析に扔いては，グループごとに母集団におけ る $\theta$ の平均抢よび標準偏差が異なる多群 IRT モデルを 適用することとした.

平均正答率の大小でみると, 生命倫理学分野におい て, 他の分野に見られない高い值が，いずれのグルー プに损いても見られた。また, 看護教育学, 読解力分 野において, 多くのグループで高い平均正答率を示し た。 それに対し，推理・分析力分野の平均正答率は低 く, また, 基礎医学科目に扔いては多くの分野で平均 正答率が低い傾向が見られた。

\subsection{2. 主成分分析による一次元性の検討}

各分野の 0-1 デー夕に対し, 背後に単一の次元を仮 定できるかを検証するため，グループごとに一次元性 の検討を行った．分野ごと，またグループごとの 0-1 デー夕に対し四分位相関係数 (tetrachoric correlation coefficient）行列を R の polycor パッケージを用いて 求め, 得られた相関行列の第 1 主成分の寄与率および 第 2 主成分の寄与率との差を算出した。 それらの值を 4 グループで平均 ${ }^{2)}$ し, 表 4 に示した。第 1 主成分の寄

2) 寄与率の平均をとることは一般的ではないが，いずれ の分野においても 4 グループ間の寄与率の值の傾向が 第 1 ・第 2 主成分ともに類似していたため, 全体の傾

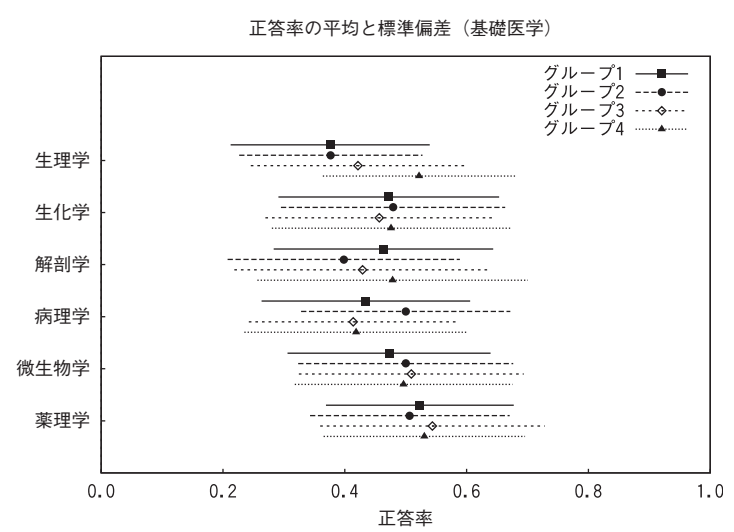

図 3. 基礎学力科目における分野別平均正答率, 標準偏差

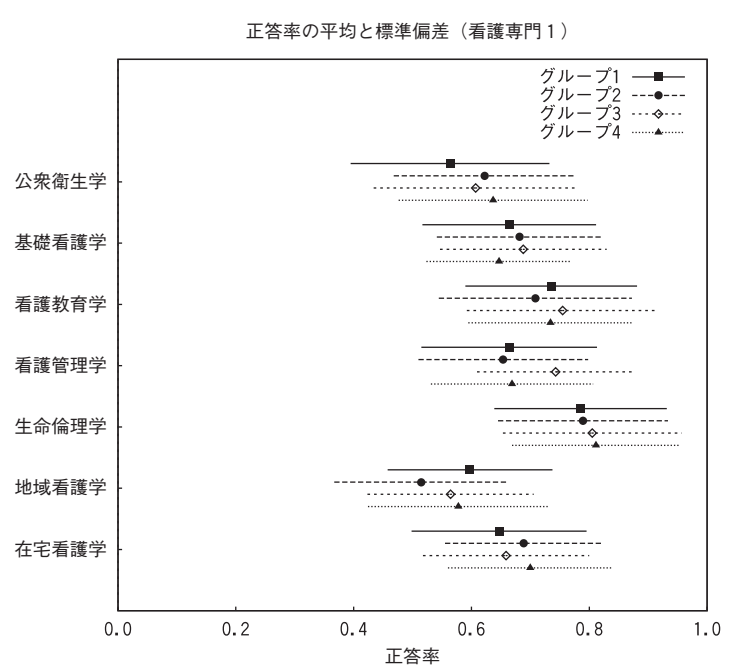

図 4. 看護専門 I 科目における分野別平均正答率, 標準偏差

与率でみると, 読解, および推理分析力において $30 \%$ 以 上の寄与率であった半面, 看護専門科目は第 1 主成分 の寄与率が最大でも $27 \%$ 前後と低く, 成人看護学のよ うに第 1 主成分の寄与率が $15 \%$ 未満という分野も見ら れた。特に, 看護専門 II 科目に捛いては, 第 1 主成分 の寄与率の大きさが小さく, 看護専門 II 科目は他の科 目に比べて分野内の一次元性が低いという傾向が見ら れた。一方, 看護管理学や生命倫理学といった分野に おいては，第 1 主成分の寄与率が $24 \%$ を超えており， これらの分野は他の分野に比べて一次元性が高い傾向 が見られた。また，基礎医学科目においては，第 1 主

向を代表する值として平均值を示した 


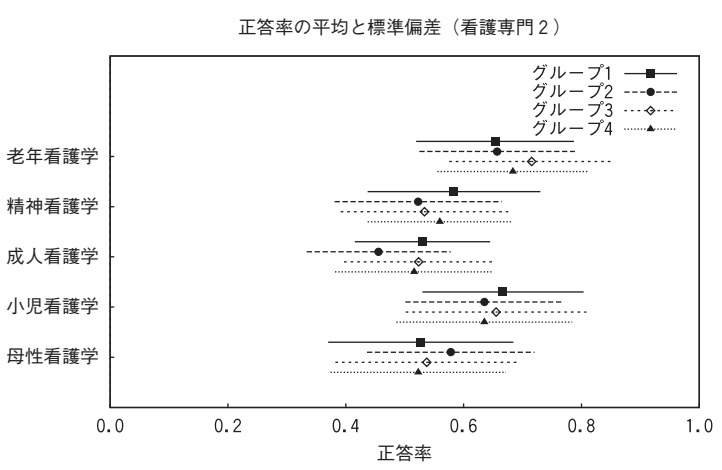

図 5. 看護専門 II 科目に打ける分野別平均正答率，標準 偏差

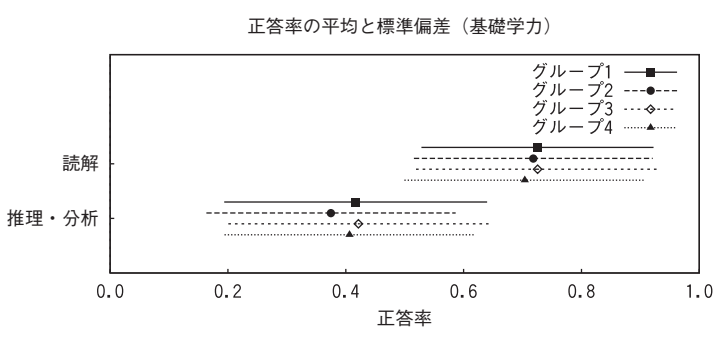

図 6. 基礎学力科目における分野別平均正答率，標準偏差

成分において薬理学を除いて $20 \%$ を超える寄与率を示 し, 基礎学力科目と看護専門科目との中間の傾向を示 した。また寄与率の差でみると，看護専門 II 科目にお いては第 1 主成分と第 2 主成分の差がいずれの分野に おいても $5 \%$ 前後, 看護専門 I 科目の地域看護学および 在宅看護学分野では $3 \%$ 前後と, いずれも小さな值で あった。また基礎医学科目においても, 生化学分野で も $3.80 \%$ と小さな值を示した。これらの分野では，第 2 主成分も大きな值を示しているという点から，一次 元性が満たされていない可能性がある。しかし他の分 野では，寄与率の大きさが $20 \%$ 超えていることから 考えて, お扔むね一次元性が満たされていると判断で きる。

一方, 科目単位で主成分分析を各グループの四分位 相関係数行列に対して行い，グループごとの平均を算 出したところ, 第 1 主成分の寄与率が基礎医学科目で $10.68 \%$ ，看護専門 I 科目で $8.70 \%$ ，看護専門 II 科目 で $9.16 \%$ と，いずれも低い值にとどまった。基礎学力 科目においては $24.93 \%$ でったが，いずれの科目に おいても，科目別に算出した場合，分野別にくらべて 一次元性がより低いという傾向が見られた。
表 4 . 第 1 主成分の寄与率および第 2 主成分との寄与率の 差. 4 グループの平均を分野ごとに示した

\begin{tabular}{crr}
\hline 分野名 & $\begin{array}{c}\text { 第 } 1 \text { 主成分 } \\
\text { 寄与率 }\end{array}$ & $\begin{array}{r}\text { 第 } 2 \text { 主成分 } \\
\text { 寄与率の差 }\end{array}$ \\
\hline 生理学 & 20.42 & 3.80 \\
生化学 & 20.85 & 4.73 \\
解剖学 & 23.25 & 5.03 \\
病理学 & 22.25 & 4.58 \\
微生物学 & 24.18 & 7.67 \\
薬理学 & 19.29 & 4.05 \\
\hline 公衆衛生学 & 20.11 & 4.51 \\
基礎看護学 & 18.93 & 7.18 \\
看護教育学 & 22.91 & 6.47 \\
看護管理学 & 27.71 & 11.91 \\
生命倫理学 & 24.28 & 8.10 \\
地域看護学 & 15.56 & 3.36 \\
在宅看護学 & 17.37 & 3.88 \\
\hline 老年看護学 & 17.46 & 5.68 \\
精神看護学 & 16.25 & 4.84 \\
成人看護学 & 13.46 & 4.84 \\
小児看護学 & 17.10 & 5.92 \\
母性看護学 & 15.58 & 5.11 \\
\hline 読解 & 31.99 & 16.45 \\
推理 ·分析 & 30.91 & 12.80 \\
\hline & &
\end{tabular}

\subsection{IRT に基づく分析}

IRT による分析は，多群 IRT モデルを適用して行っ た. 本節では，「分野別の推定」および「科目単位の推 定」のそれぞれの場合で，項目パラメ夕の推定結果が どのように異なるかを示した.

\subsection{1. 項目パラメタの推定值}

識別力および困難度の推定值において, 絶対值が 10 を超える極端な推定值となった項目は，いずれの分野， いずれの推定方法においても見られなかった．推定の 段階で, 老年看護学の 1 項目について,「分野別の推定」 を行った場合, 科目でまとめて推定した結果よりも著 しく大きな識別力の推定値となった（「分野別の推定」 1.039 ,「科目単位の推定」0.200). 当該科目について は, 識別力の事前分布の平均, すなわち過去に同一項 目を提示した時点における識別力の推定值が 0.388 で あることを考えると, 当該項目の真の識別力は, 科目 でまとめて推定したときの值に近い值であると考える ことができる，以下の分析結果では，当該項目を含め 
comparison of slope : BISEIBUTU

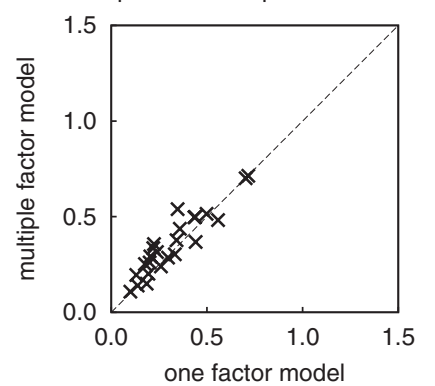

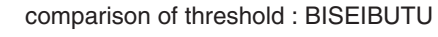

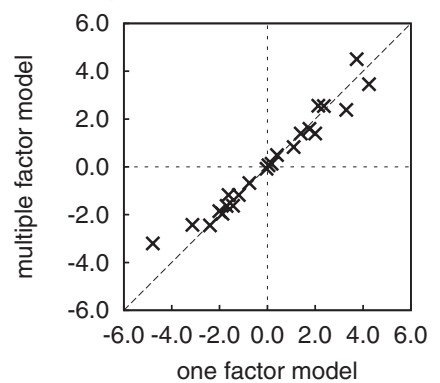

comparison of TIC : BISEIBUTU

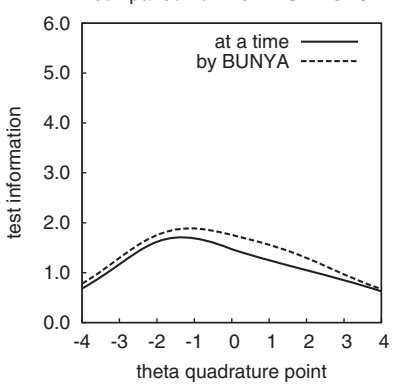

図 7. 微生物学 (基礎医学科目) における項目パラメ夕推定值の差異（左および中央）およびテスト情報量の差異（右）. 項目パラメ夕の差異については, 横軸に「基礎医学」科目をまとめて推定した場合, 縦軸に分野ごとに推定した場合 のパラメタ推定結果を項目ごとに示した．左は識別力，中央は困難度を示した

comparison of slope : YAKURI

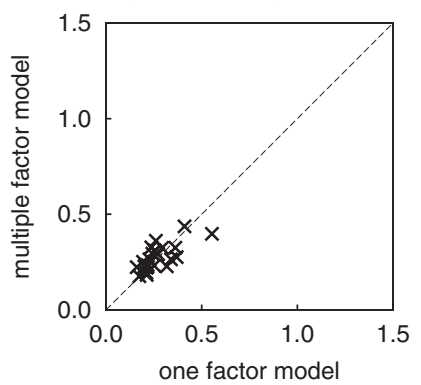

comparison of threshold : YAKURI

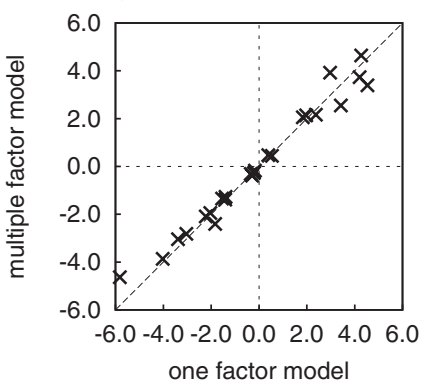

comparison of TIC : YAKURI

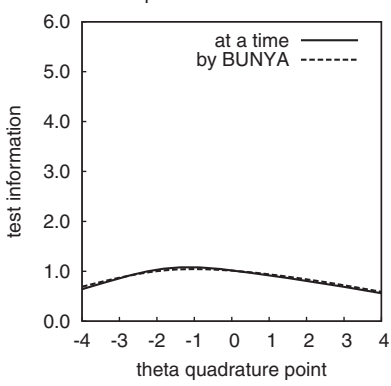

図 8. 薬理学（基礎医学科目）に抢ける項目パラメ夕推定值の差異 (左および中央) およびテスト情報量の差異（右). 項 目パラメ夕の差異については，横軸に「基礎医学」科目をまとめて推定した場合，縦軸に分野ごとに推定した場合の パラメタ推定結果を項目ごとに示した. 左は識別力, 中央は困難度を示した

comparison of slope : KANRI

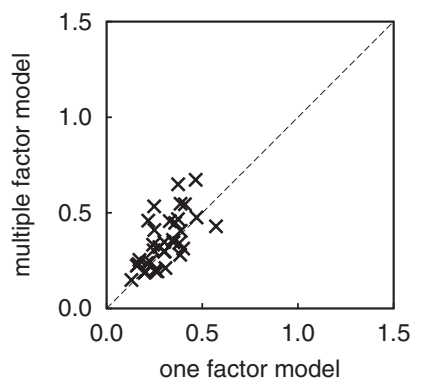

comparison of threshold : KANRI

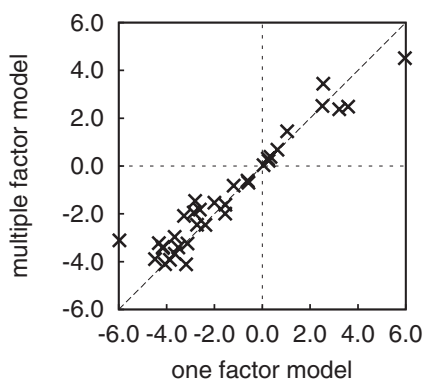

comparison of TIC : KANRI

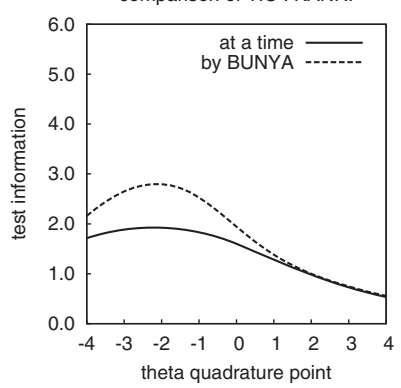

図 9. 看護管理学 (看護専門 I 科目) における項目パラメ夕推定值の差異 (左および中央) およびテスト情報量の差異 (右). 項目パラメ夕の差異については, 横軸に「看護専門 I」科目をまとめて推定した場合, 縦軸に分野ごとに推定した場 合のパラメタ推定結果を項目ごとに示した. 左は識別力, 中央は困難度を示した

た結果を示している。

基礎医学科目で第 1 主成分の寄与率が最も大きかっ た「微生物学」と最も小さかった「薬理学」において, 「分野別の推定」および「科目単位の推定」それぞれに ついて項目パラメタの差異を散布図で示した（微生物
学; 図 7 左および中央, 薬理学; 図 8 左および中央). 困に，看護専門 I 科目で第 1 主成分の寄与率が最も大 きかった「看護管理学」および寄与率が最も小さかっ た「地域看護学」におけるパラメタの差異を示した（看 護教育学; 図 9 左および中央, 基礎看護学; 図 10 左お 
comparison of slope : $\mathrm{CHIIKI}$

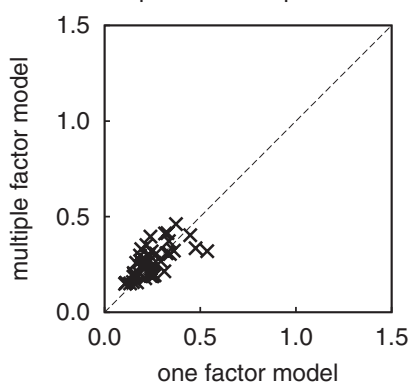

comparison of threshold : $\mathrm{CHIIKI}$

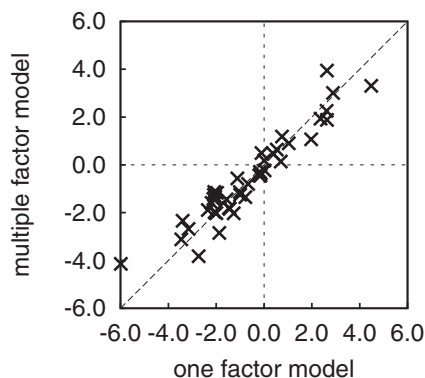

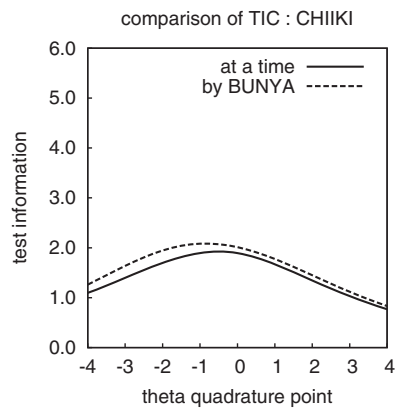

図 10. 地域看護学（看護専門 I 科目）における項目パラメ夕推定值の差異（左および中央）およびテスト情報量の差異 (右). 項目パラメタの差異については，横軸に「看護専門 I」科目をまとめて推定した場合，縦軸に分野ごとに推 定した場合のパラメタ推定結果を項目ごとに示した．左は識別力，中央は困難度を示した

comparison of slope : SYOUNI

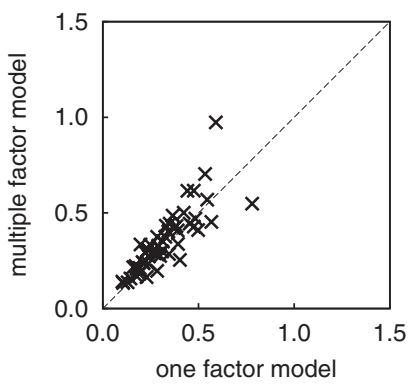

comparison of threshold : SYOUNI

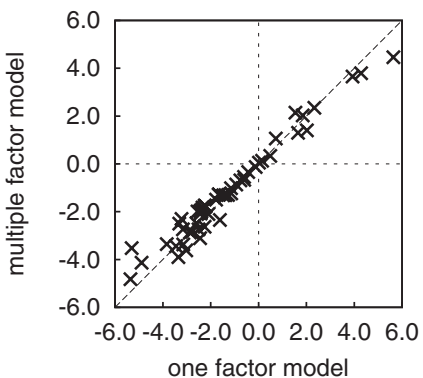

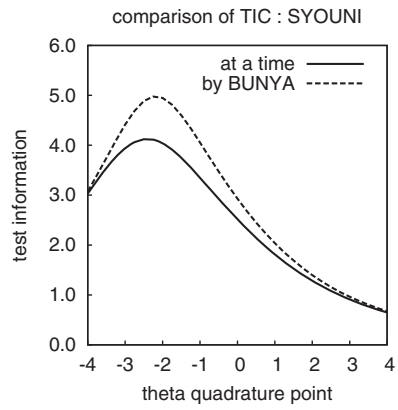

図 11. 小巟看護学 (看護専門 II 科目) における項目パラメ夕推定值の差異（左および中央）およびテスト情報量の差異 (右). 項目パラメタの差異については, 横軸に「看護専門 II」科目をまとめて推定した場合, 縦軸に分野ごとに推 定した場合のパラメタ推定結果を項目ごとに示した．左は識別力，中央は困難度を示した

comparison of slope : SEIJIN

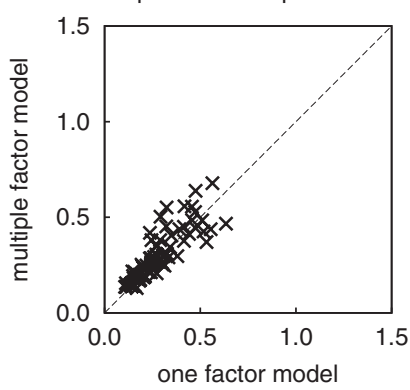

comparison of threshold : SEIJIN

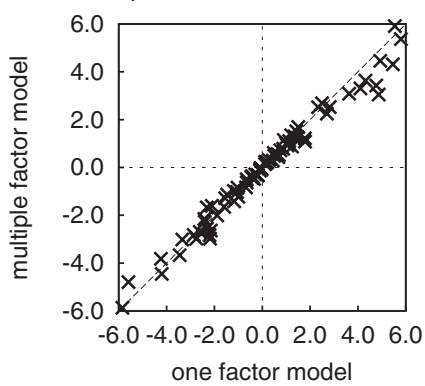

comparison of TIC : SEIJIN

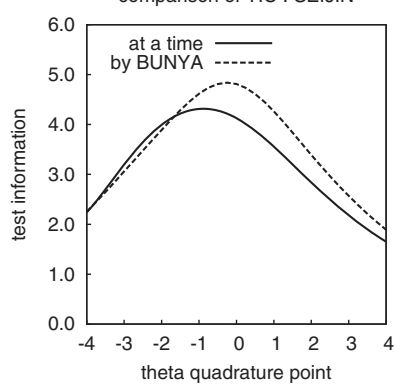

図 12. 成人看護学（看護専門 II 科目）における項目パラメ夕推定值の差異（左および中央）およびテスト情報量の差異 (右). 項目パラメ夕の差異については, 横軸に「看護専門 II」科目をまとめて推定した場合, 縦軸に分野ごとに推 定した場合のパラメタ推定結果を項目ごとに示した. 左は識別力, 中央は困難度を示した

よび中央)。さらに，看護専門 II 科目においては，等 化デザインが他の科目と異なり，かつ第 1 主成分の寄 与率が大きかった「小児看護学」と，第 1 主成分の寄 与率が最も小さかった「成人看護学」におけるパラメ 夕の差異を散布図で示した（小児看護学；図 11 左およ
び中央，成人看護学；図 12 左および中央)。また，各 分野について「分野別の推定」および「科目単位の推 定」それぞれの場合で推定されたテスト情報量曲線を 比較した（図 7 から図 12 右に示した).さらに, 表 5 に項目パラメタの推定值の要約統計量を, 推定方法別 
表 5. 分野別に推定した場合と科目単位で推定した場合で の項目パラメ夕の推定值の平均および標準偏差. 分 野ごとに示した。 $A^{*}$ はパラメ夕推定された項目数 を示す

\begin{tabular}{ccccrr}
\hline & & \multicolumn{2}{c}{ 識別力 } & \multicolumn{2}{c}{ 困難度 } \\
\cline { 3 - 6 } 分野名 & $A^{*}$ & 科目別 & 分野別 & 科目別 & 分野別 \\
\hline 生理学 & 24 & 0.254 & 0.271 & 1.153 & 0.941 \\
生化学 & 20 & 0.274 & 0.295 & 0.622 & 0.596 \\
解剖学 & 16 & 0.299 & 0.319 & 0.563 & 0.448 \\
病理学 & 20 & 0.292 & 0.288 & 0.813 & 0.666 \\
微生物学 & 24 & 0.322 & 0.357 & 0.329 & 0.306 \\
薬理学 & 24 & 0.267 & 0.271 & -0.051 & -0.018 \\
\hline 公衆衛生学 & 24 & 0.263 & 0.302 & -0.810 & -0.870 \\
基礎看護学 & 52 & 0.305 & 0.331 & -1.241 & -1.154 \\
看護教育学 & 24 & 0.280 & 0.317 & -2.030 & -1.831 \\
看護管理学 & 36 & 0.303 & 0.349 & -1.671 & -1.409 \\
生命倫理学 & 36 & 0.395 & 0.459 & -2.300 & -2.050 \\
地域看護学 & 43 & 0.248 & 0.264 & -0.640 & -0.588 \\
在宅看護学 & 44 & 0.271 & 0.304 & -1.471 & -1.319 \\
\hline 老年看護学 & 47 & 0.306 & 0.319 & -1.705 & -1.649 \\
精神看護学 & 52 & 0.288 & 0.297 & -0.757 & -0.704 \\
成人看護学 & 81 & 0.276 & 0.294 & 0.171 & 0.063 \\
小児看護学 & 53 & 0.319 & 0.347 & -1.331 & -1.224 \\
母性看護学 & 52 & 0.304 & 0.315 & -0.300 & -0.302 \\
\hline 読解 & 8 & 0.552 & 0.577 & -1.337 & -1.385 \\
推理 ·分析力 & 7 & 0.429 & 0.455 & 0.889 & 0.941 \\
\hline 学 & & & & &
\end{tabular}

に示した。

基礎医学科目においては, 図で示した微生物学と薬 理学についてみると, 眓 7 中央と図 8 中央の比較より, いずれの分野でも $\theta$ の絶対值の大きな項目において困 難度の推定結果に差異が見られた。 また, 図 7 左と図 8 左の比較から, 識別力の推定值はいずれの分野におい ても「識別力の大きな項目の推定結果について, 推定 值がばらつく」という傾向が見られ，表 5 より，微生 物学における平均識別值は分野別の推定において高い 值を示した。また，図 7 右と図 8 右の比較により，い ずれの分野においてもテスト情報量曲線に推定方法間 の大きな違いは見られなかった。

看護専門 I科目について結果をみると, 図 9 左と図 10 左の比較および表 5 から, 第 1 主成分の寄与率が大き かった看護管理学分野において,「分野別の推定」に よる識別力の推定值が，「科目単位の推定」による識別
表 6 . 基礎医学科目の $\theta$ の相関行列

\begin{tabular}{lllllll}
\hline & 生理 & 生化 & 解剖 & 病理 & 微生 & 薬理 \\
\hline 生理 & 1.00 & 0.24 & 0.23 & 0.18 & 0.24 & 0.19 \\
生化 & & 1.00 & 0.25 & 0.28 & 0.23 & 0.28 \\
解剖 & & & 1.00 & 0.24 & 0.25 & 0.27 \\
病理 & & & & 1.00 & 0.30 & 0.25 \\
微生 & & & & 1.00 & 0.30 \\
薬理 & & & & & & 1.00 \\
\hline
\end{tabular}

力の推定值に比べて大きくなる傾向が見られた。この 傾向は, 識別力の推定值が大きな項目において顕著で あった。一方，第 1 主成分の寄与率が小さかった地域 看護学においては,「分野別の推定」による識別力の方 が大きい值をとる傾向が見られたものの, 看護管理学 の場合と比べて, 顕著ではなかった。また, 困難度の 推定值の差異でみると, 図 9 中央と図 10 中央の比較 より, 困難度の低い項目において「分野別の推定」に よる場合の推定值がより大きな困難度と推定される傾 向が見られた。この傾向は, 看護管理学の場合で顕著 であった。さらに，テスト情報量曲線の差異でみると， 眓 9 右と図 10 右の比較より, 看護管理学においては $\theta$ の低い受験者に対するテスト情報量について差が大 きいという結果であった。

看護専門 II 科目についてみると, 図 11 左と図 12 左 の比較および表 5 より, 小児看護学, 成人看護学の双 方において, 全体的に見て,「分野別の推定」の場合の 方が大きな識別力の推定結果となったが, 増加幅は小 児看護学がより大きかった。また，図 11 中央と図 12 中央の比較から, 看護専門 I 科目の 2 分野で見られた 傾向と同様に, 困難度の小さな項目について,「分野別 の推定」による方がより大きな推定值を示した。また， 困難度の大きな項目についてみると,「分野別の推定」 の方が「科目単位の推定」の場合に比べ, 困難度の推 定值が小さくなる傾向が見られた。 さらに, 四 11 右 と図 12 右の比較より,「分野別の推定」の方が大きな テスト情報量のピークとなる傾向が見られた。 ただし， ピークとなる $\theta$ の值は, 分野ごとに別々に推定した場 合， $\theta=0$ となる点に近づく傾向が見られた。この傾 向は, 看護管理学分野では見られなかった。

\subsection{2. 能力値の推定值}

分野間の推定における $\theta$ の相関 表 6 に, 基礎医学科 目について「分野別の推定」を行った場合の, 分野間 の $\theta$ の相関行列を示した。 また, 表 7 , 表 8 に, 看護 
表 7. 看護専門 I 科目の $\theta$ の相関行列

\begin{tabular}{llllllll}
\hline & 公衆 & 基礎 & 地域 & 在宅 & 教育 & 管理 & 生命 \\
\hline 公衆 & 1.00 & 0.29 & 0.26 & 0.24 & 0.22 & 0.23 & 0.22 \\
基礎 & & 1.00 & 0.32 & 0.37 & 0.30 & 0.32 & 0.35 \\
地域 & & & 1.00 & 0.26 & 0.26 & 0.24 & 0.25 \\
在宅 & & & & 1.00 & 0.26 & 0.29 & 0.29 \\
教育 & & & & & 1.00 & 0.29 & 0.24 \\
管理 & & & & & & 1.00 & 0.28 \\
生命 & & & & & & & 1.00 \\
\hline
\end{tabular}

表 8. 看護専門 II 科目の $\theta$ の相関行列

\begin{tabular}{cccccc}
\hline & 成人 & 老年 & 小览 & 母性 & 精神 \\
\hline 成人 & \multirow{2}{*}{1.00} & 0.34 & 0.39 & 0.45 & 0.39 \\
老年 & & 1.00 & 0.40 & 0.33 & 0.37 \\
小児 & & & 1.00 & 0.36 & 0.34 \\
母性 & & & & 1.00 & 0.37 \\
精神 & & & & & 1.00 \\
\hline
\end{tabular}

専門 I，看護専門 II 科目に扮ける $\theta$ の相関行列をそれ ぞれ示した。また，基礎学力科目に扔いて，「読解」お よび「推理・分析」の 2 分野における $\theta$ の相関係数は, 0.40 であった。基礎医学科目相互間において $\theta$ の相関 が低く，看護専門 I，看護専門 II において相関が高い 傾向が見られた。

推定方法間の $\theta$ 推定值の差異 図 13 に, 基礎医学科 目について「分野別の推定」による合成得点と，「科 目単位の推定」の場合の $\theta$ を各受験者についてプロッ 卜した結果を示した。また, 図 14 に看護専門 I 科目, 図 15 に看護専門 II 科目, 図 16 に基礎学力科目につ いて，それぞれ同様の散布図およびヒストグラムを示 した。基礎医学科目では， $\theta$ が小さな受験者において, 分野別の $\theta$ から算出した合成得点の方が科目全体での $\theta$ に比べて大きく推定された。また $\theta$ が大きな受験者 に扔いては，合成得点の方が科目全体における $\theta$ に比 べて小さく推定された。、いずれの差異も， $\theta$ が 0 付近 の受験者に扔いては 0.1 前後と大きな差ではなかった (科目全体で推定した $\theta$ の標準誤差の推定值は 0.55 前 後であり，ほぼこれに相当する差異であった)。

また，最も $\theta$ が大きかった受験者においては，合成 得点が 2.517 であるのに対し，科目全体の $\theta$ は 3.029 となり, 差は 0.512 と大きくなった。同様の傾向は看 護専門 I 科目や看護専門 II 科目でも見られ，看護専門 科目 I では最大の $\theta$ の受験者についてみると, 合成得

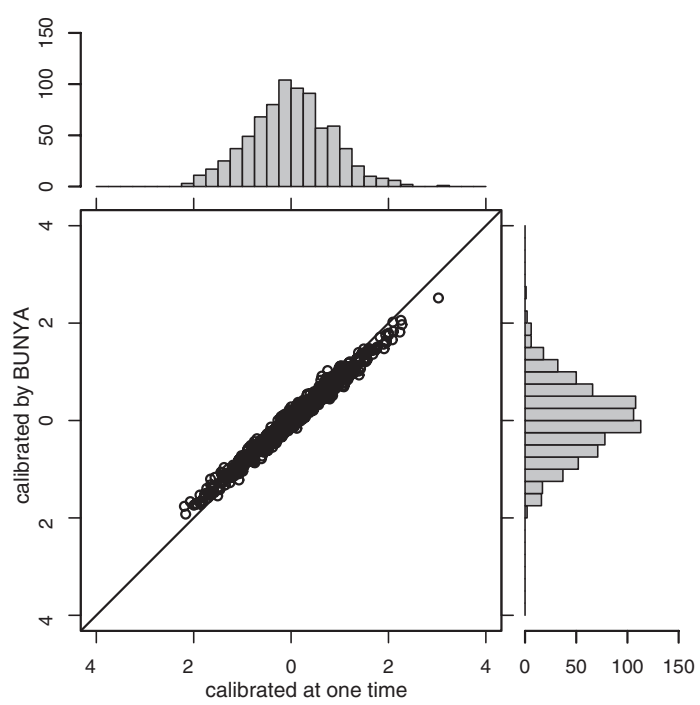

図 13. 基礎医学科目における $\theta$ の散布図および周辺分布

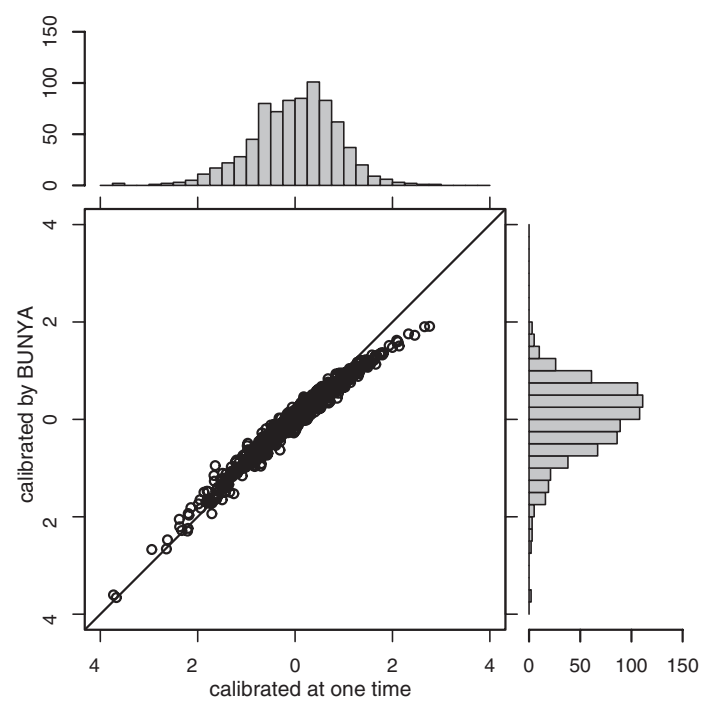

図 14. 看護専門 I 科目における $\theta$ の散布図および周辺分布

点が 1.910 に対し, 科目全体での $\theta$ が 2.763 で, 0.853 の差がみられた。また看護専門 II でみると, 最大の $\theta$ の受験者に扔いて合成得点が 2.314 であるのに対し科 目全体での $\theta$ が 3.207 と, その差が 0.893 となった. さらに, 基礎学力科目でみると, 最大の $\theta$ の受験者で, 合成得点が 1.404 であるのに対し，科目全体での $\theta$ は 1.913 と, その差が 0.509 であった. $\theta$ が小さな值の受 験者についても， $\theta$ が大きな受験者ほどではないもの 


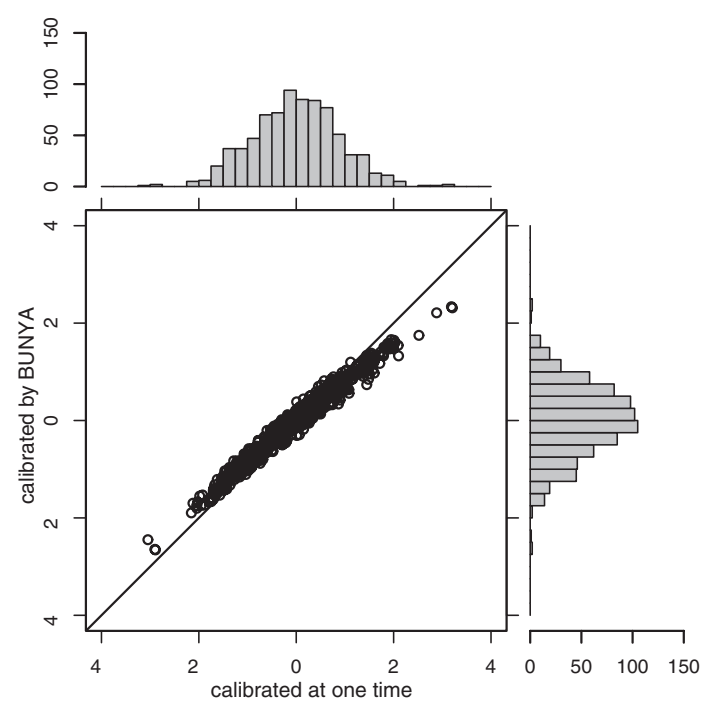

図 15. 看護専門 II 科目における $\theta$ の散布図および周辺 分布

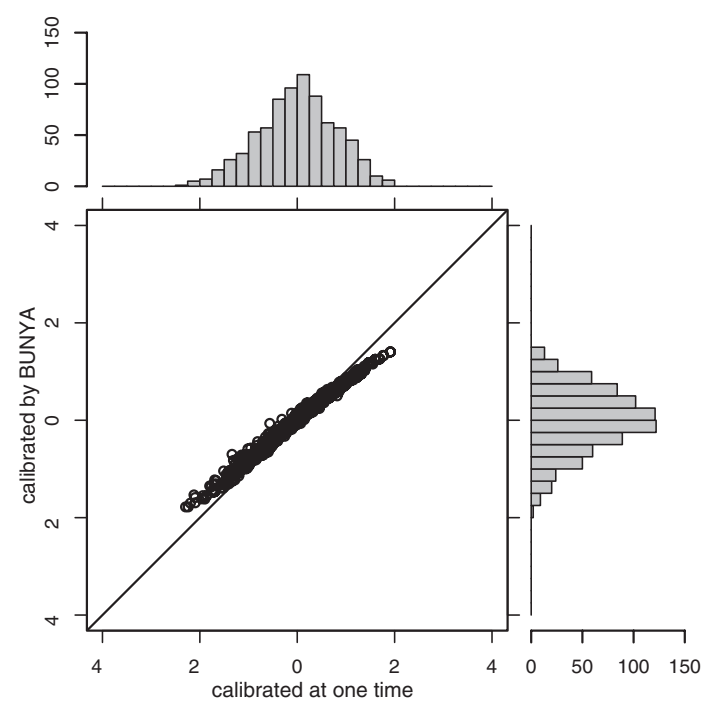

図 16. 基礎学力科目における $\theta$ の散布図および周辺分布

の，同様に合成得点と科目全体での $\theta$ の間に大きな差 が見られた。これらの傾向は，特に看護専門 $\mathrm{I}$ 科目と 看護専門 II 科目において，合成得点のヒストグラムが 科目全体での $\theta$ の分布に比べ, 全体的に平均の周りに シュリンクしていることからもわかる。 また, 看護専 門 I 科目㧍よび看護専門 II 科目は，相関行列の值が特 に大きかった科目である。 $\theta$ のヒストグラムの比較 $\theta$ のヒストグラムについて みると, 看護専門 I 科目に扔いて「科目単位で推定」の 場合, 単峰でない $\theta$ の分布となった。 それ以外の科目 については，推定方法による分布形状の違いは見られ なかった。

\section{4. 考察}

\section{1. 項目パラメタ推定結果の差異}

本研究では, パラメ夕を分野ごとに別々に推定した 場合と, 科目ごとに合わせて推定した場合とで, 推定 結果がどの程度異なるかを検討した。主成分分析から， 分野ごとに推定した場合であっても, 分野によっては 一次元性が十分に見られないという結果であった。こ れらを併合した「科目」のレベルであっても, 一次元 性が十分に仮定できない尺度に対し, 一次元の $\theta$ を仮 定するモデルを適用することは，モデルのあてはまり という点では望ましくない結果となることは明らかで ある。そこで,「科目」ではなく，それぞれの尺度にお いてょり一次元性が高いと予測される「分野」のレベ ルで別々に $\theta$ の尺度を構成し, 合成得点の形で「科目」 単位の成績を表示する方法により, IRT の前提の一つ である「一次元性」をより満たしつつ, 得られた項目 パラメタの值が「科目」単位で推定した場合と同様に 解釈可能かどうか検討を行った.

本研究で取り扱った分野は, いずれも看護大学に在 籍する臨地実習前の学生にとって, 必要な知識とされ る内容であった。しかし，たとえば「看護専門 I」よ りも「看護専門 II」科目に扔いて, より発展的・応用 的な内容であるといった特徵がある。また「基礎医学」 科目は, 「看護専門」科目に比べ, 看護大学生にとって 発展的な内容であるといえる。このように, 科目ごと の特徵を述べるならば,「看護専門 I」および「看護専 門 II」のスコアによって臨地実習前の必須知識, ひい ては適性を予測することができるといえる。これら 2 科目に扔いては，全体的にテスト情報量が大きいとい う結果から, 本テストで提示された項目は受験者の臨 地実習前に打ける適性を判断する材料として機能する ことが示唆される。 また，各分野に扔いて推定された $\theta$ の相関が高かった看護専門 I 科目, 看護専門 II 科目 および基礎学力科目において,「分野別の推定」の結果 においてテスト情報量が大きく推定された一方， $\theta$ の 相関が低かった基礎医学科目においては「分野別の推 定」「科目単位の推定」いずれの方法でもテスト情報量 
が高まらなかった．特定の $\theta$ に対する情報量が「分野 別の推定」によって高まった理由としては, 看護専門 科目および基礎学力科目において，「それぞれの分野の 間で似た概念を測定している一方，分野内でも単一の 概念を測定している」ということを，「分野別の推定」 の方がよりモデル上で適切に説明しているためである と考える。「科目単位で推定」の場合,「分野内で単一 の概念を測定」しているかどうかをモデル上で表現で きないため, その分, 得られるテスト情報量が低下し ていると考える。一方, 基礎医学科目は，主成分分析 の結果から，各分野で問われている内容がそれぞれの 分野内で特徵づけられていることが明らかである。一 方, 分野をまたいだ「一次元性」が, 看護専門科目に比 べて低いことが推測される。このため，「分野の違い」 をモデル上で表現しない「科目単位で推定」した場合 では，分野の違いを表現できないためにテスト情報量 が低く推定されたと考える。このように, 基礎医学科 目と「看護専門科目扔よび基礎学力科目」は，それぞ れ科目の持つ性質が異なることが, 本研究の結果から 推測される.

等化デザインの違いが項目パラメタ推定結果に与え る影響についてみると, 看護専門 II 科目の「小児看護 学」と「成人看護学」で, 得られたパラメ夕の傾向が 大きく異ならなかったことは，等化デザインの違いに よって項目パラメ夕の推定值が左右されない可能性を 示唆する。一般に，ユニークアンカーデザインでは， 項目バンク中にあるアンカー項目候補に「識別力が高 く, 困難度が適度」な項目が多い場合, それらの項目を アンカー項目とすることが可能な一方, 共通アンカー デザインではそのような項目パラメタが良好な項目が 少なくてもよいという利点がある. しかし, 共通アン カーデザインに拈いては, アンカー項目の項目バンク 上に扔ける困難度が実際の受験者とマッチしていない と, 等化の精度に大きく影響する一方, ユニークアン カーデザインにおいてはそのような心配がない。本研 究においては, 良好な項目パラメ夕をもつ項目群が項 目バンク内に十分存在しない場合に, やむを得ず共通 アンカーデザインを用いた。それがユニークアンカー デザインをとった他の分野と同等な結果となったのは, 受験者の能力レベルと, アンカー項目の困難度が一致 していたからであるという要素を指摘できる。この点 は, 試験を実施する前にある程度統制することは可能 ではあるものの, 確実に受験者の能力レベルと項目困 難度を一致させる方法は限られる。しかし, 能力レベ
ルと困難度が一致した場合は, 共通アンカーデザイン が項目バンクを構成するうえで有用であることを本研 究の結果が示しているといえる.

\subsection{2 種のパラメタ推定方法と実践場面との関連} 本研究で構成された項目バンクを用いて今後 CBT を行う際，パラメ夕の推定方法が異なる 2 種類のパラ メタのうちいずれがふさわしいかに関して，(1) 項目 パラメタおよび $\theta$ の推定值の特徴, (2) 項目パラメ夕 推定の技術上の問題，の 2 点について, 以下に述べる.

(1)については, 看護専門科目および基礎学力科目に 挍いて,「科目単位の推定」に比べて「分野別の推定」 の場合にテスト情報量が大きい傾向が見られ，特定の $\theta$ に扔いて顕著な情報量の差となる傾向が見られた。こ のことは，これらの科目に扔いて，各分野がそれぞれ の専門性を反映した尺度を構成しており，これらを併 合した「科目単位」で推定した結果よりも高い識別力, すなわち信頼性をある $\theta$ の範囲について有していると 解釈できる。逆に言えば，科目単位による項目パラメ 夕の推定結果は，テストの実践上，特定の $\theta$ に対する 情報を損なう恐れがあることが指摘できる。したがっ て, 看護専門科目および基礎学力科目については, 「分 野別の推定」の方がより受験者の成績を判断するため に有益なツールとなる尺度が得られることが示唆され る. 一方, 基礎医学科目については, 分野ごとに別々 に推定した場合と科目単位でまとめて推定した場合で テスト情報量に大きな違いは見られなかった。しかし ながら, 基礎医学科目に扔いて, それぞれの分野を精度 よく問うような項目が多く出題されるようになること が将来起これば, 科目をまとめて推定した場合に, 分 野ごとに推定すれば高くなったはずの識別力が過小に 推定される可能性がある。したがって, 基礎医学科目 に扔いても，「分野別の推定」の方が望ましいことが示 唆される.

また， $\theta$ の推定に扔いても，「分野別の推定」による 項目パラメ夕を用いて求めた $\theta$ が妥当であると示唆さ れる，分野ごとに個別に $\theta$ を推定した場合に，それぞ れの $\theta$ の精度が高まるという佐藤・柴山 (2011) の結 果からも, 分野ごとに個別に項目パラメ夕を推定した 方がより望ましい結果を得ることができることが指摘 できる.「科目単位の推定」では, 特定の $\theta$ の範囲に関 する情報が損なわれているため, その範囲の受験者に ついて, $\theta$ の推定精度が低下する。 そのため, 受験者 に十分な適性があるかどうかを判断するための材料と 
して妥当ではなくなる可能性が指摘できる.

さらに, 合成得点と科目ごとに求めた $\theta$ との比較で, 科目単位による $\theta$ が值の範囲の大きな傾向がみられた。 このことは, 特に $\theta$ の低い部分に関して, 情報量がか け離れている傾向とは別の要因によると指摘できる。 現時点ではその要因に関しては明らかではないと考え る.しかし, 実践上, 極端な $\theta$ の值が出現することは, $\theta$ の值を線形変換等により尺度得点とする際，極端な 尺度得点の值が出現することになり, 解釈上の問題が 生じることが指摘できる。

(2) については, 本研究において項目パラメ夕を推 定する際, 少ない人数のデー夕から解釈可能な項目パ ラメ夕の推定值を得るために, 以前の研究で得られた 推定結果を事前分布の形で利用した。この方法をとら ずに，実受験者のデータのみから項目パラメ夕を推定 する場合は，より推定が安定する方法によることが実 践上重要である. 受験者数が十分多い場合は,「分野別 の推定」でも「科目単位の推定」でも同程度の安定性で あることが予想されるものの, 受験者数が少ない場合 は, 項目数が多いと推定が安定しない傾向が見られる ことが予想される。しかしな゙ら, 項目推定の安定性 は，どれだけデー夕がモデルに当てはまるかによると ころが大きい。したがって, 実践場面においては, いず れの方法をとるにしても, 項目パラメタ推定が安定し ない可能性を考慮してテストデザインを組むことが必 要だと考える。また, 多群 IRT モデルを用いる場合, 共通アンカーデザインは項目全体に占めるアンカー項 目の割合がユニークアンカーデザインょり小さくなる ため, 推定が不安定になる要因になることも指摘でき る。ただし，分野ごとに個別にパラメ夕推定する操作 は, 科目単位で一括して推定するよりも, 分野の数だけ データの加工や整理といった作業の手間が増え, 誤り を犯す可能性も高まることが予想され，この点では科 目単位での推定がより望ましいことが指摘できる。な お, 老年看護学分野の 1 項目について, 「分野別の推 定」により識別值の過大推定が発生した。これは，実 際の受験者が少ないことへの対処として，事前分布の 設定等の措置を講じたために生じたためであり，テス 卜実践場面に㧍いてはこのような項目を除外して項目 バンクを構築することにより，対処できると考える.
成のためのトライアル試験のデータを分析した結果, （1）分野別に推定した場合の方が，科目別に推定した 場合に比べて識別力が大きい傾向がみられ, 看護専門 科目に拈いてはテスト情報量も大きい, (2) $\theta$ の推定に 関しても, その範囲が分野別の推定において広い傾向 にある，といったことが明らかになった。またパラメ 夕推定の技術上の観点から, (3) 分野別推定が安定す る傾向がみられる, (4) 分野別の推定の場合, 分野単位 で推定の手続きを行うため, 処理が複雑になる, とい うことが指摘できる，以上より，推定手続きの複雑さ に対応できる試験実施体制が整うのであれば, 分野別 の推定を行った方が良いと結論できる。また，テスト デザイン上の観点からは, 看護専門 II 科目における 2 分野の項目パラメタ推定值の比較結果より, アンカー 項目の困難度に一致する $\theta$ を持つ受験者が受験すると いう, IRT のモデルに沿った状況であれば, 共通アン カーデザインを用いることが有効であるといえる.

本研究では, 項目バンク構築のためのパラメ夕推定 場面を取り上げた。しかし，実際に CBT を実施する にあたっては, 本試験受験者に「成績判断に使用されな いが項目パラメ夕推定を行う」項目群を提示し, これら の項目群を項目バンク上の尺度に等化することで, 項 目のバリエーションを増やしていく過程が必要である. その際，本試験の成績の精度が低下することが予想さ れるが, 新規に項目パラメ夕を推定すべき項目数が多 い場合に, どの程度の新規項目数であれば推定精度の 低下が許容されるかを明らかにする必要がある。また， 看護学および医学上の新たな知見を反映させた新作項 目を取り入れる過程に扔いては, 科目及び分野の見直 しといった「カリキュラムの刷新」を行わなければな らない.カリキュラムの刷新に当たっては, 既存の分 野を統合または分割することが求められるため, それ らに向けた等化やリンキング (linking) の方法論的検 討が不可欠である。このような項目バンク構築場面で の等化㧍よびリンキングの事例において, 複数の分野 の扱いをどのようにするか, シミュレーションを含め たさらなる研究が必要であると考える. 同時に, 亀井 ほか (2013) で示されるような, 項目の「質」に関する 議論を継続的に行うことが, CBT の妥当性を高めるう えの課題であるといえよう.

\section{5. 結論および今後の課題}

看護系大学共用 $\mathrm{CBT}$ の実施に向けた項目バンク作 


\section{6. 付}

\section{録}

\section{1. 本トライアル CBT で基礎学力科目を提示し た理由}

石井ほか (2007) では看護学科の大学教員に対して, また，石井ほか (2003) では学生に対して，それぞれ授 業場面に损ける態度に関する調査を行っている。これ らの 2 研究より, 看護系の大学において特有の「共感」 スキルといった要素が, 他の学部専攻と比較して向上 していることが見出された。ささらに，これらの研究を 踏まえ, 看護専門科目や基礎医学科目のほかに, 看護 師になるための適性を判断する材料として，高校卒業 時までのカリキュラムでは測定されにくい「新学力観」 の存在を提示した研究 (柳井・石井, 2007) がある.こ の研究では,「論理的思考力」「持続力」「文章表現力」 「探究心」「自己表現力」といった資質が学年の経過に 伴い上昇していることを指摘し, 看護教育によってこ れらの「新学力観」が培われている傾向にあると結論 づけている，同時に，教員から見て，これらの資質が 学生に備わっていると判断される度合いが低いと判断 されていることを指摘している，以上の前提から，看 護 CBTに扔いて,「論理的思考能力」や「文章読解力」 を測定する項目を「基礎学力科目」として導入し, 受 験者に課すこととした。

\section{2. 一次元を仮定したIRT を適用する理由}

項目パラメ夕推定に関しては, 適切なモデルの選択 という観点において，MIRT モデルを適用すべきかど うかといった議論がある。とりわけ，分野による得意 不得意が大きい受験者が多く存在するグループに対す る試験の場合，受験者が得意とする分野において正答 数が多く，不得意な分野に正答数が少ないという「受 験者の能力と項目パラメ夕の交互作用」が見られるこ とが事前に分かっているため, 一次元を仮定した IRT モデルよりも MIRT モデルを適用すべきとの指摘があ る (Reckase, 2009, pp.53-54). しかし，(1) 本 CBT が実際に試験として実施された場合，新たな受験者に 対して項目パラメタ未知の項目を提示し, MIRT モデ ルを適用した上で，複数次元のテストを同時に等化す ることが必要となり，この一連のプロセスを安定して 実施するためには，MIRT モデルのパラメ夕推定およ び等化の方法論的考察が現時点では発展途上であると 言わざるを得ない，(2) MIRT モデルを適用した場合， 受験者の適性の高低を「臨地実習を行わせてもよいか
否か」の判断材料とする場合, 複数次元得られる $\theta$ の 值を一つの合否基準に当てはめる際の方法をどうする かという問題が生じる，(3) 本 CBT の場合のように, 12 分野, すなわち 12 次元の $\theta$ が仮定されるデー夕に 対するMIRT モデルを考えなければならない場合，そ のモデルは非常に複雑であり, 推定が不可能になる可 能性が高い, といった理由により, 本研究では MIRT モデルではなく，一次元を仮定した IRT モデルを適用 した場合を考えた。

\section{3. 項目パラメタ推定の手続き}

IRT の分析にあたっては, 基礎学力科目以外で, 各 グループでの受験者数が少ないため, BILOG-MGの デフォルトの設定による分析では解を求めることがで きなかった（基礎学力科目においては 4 グループに共 通の項目を出題しているため, 以下に述べる事前確率 分布の指定は行っていない). 本研究においてはグルー プ一つ当たりの受験者数が少ないようなデー夕を用い て安定した項目パラメタ推定を行う必要がある。村木 (2011)は, BILOG-MG を用いた項目パラメ夕の推定 に際し,「項目除去は事前確率分布の調節やそのほか の対策を講じてからの最終的な選択である」と指摘し ている (p.121)ことから, 本研究では事前分布を指定 する方法をとることとした。事前分布は識別力, 困難 度それぞれのパラメタについて平均および標準偏差を 指定するが，本研究で用いた項目群は柳井ほか (2012) において出題されており，ここで算出された項目パラ メ夕の点推定值を事前分布の平均とした。また標準偏 差については，その值を小さくすることで項目パラメ 夕推定が安定する (村木, 2011, p.121) が，ある程度大 きな值としなければ, 事前分布の平均から推定結果が 大きく動かなくなる恐れがある. 本研究では, 安定し た項目パラメ夕推定が可能な事前分布の標準偏差とし て, BILOG-MG のデフォルト值である 1.648 (識別 力）抽び 2.0 (困難度) を用いた。ただし，「分野別 の推定」において, 看護専門 I で 1 項目 (地域看護学), 看護専門 II で 4 項目（成人看護学 3 項目, 母性看護 学 1 項目) について, 点双列相関係数が BILOG-MG の基準である -0.15 を下回ったため, 推定から除外し た。同様の理由で,「科目単位の推定」の場合において も, 看護専門 II で 2 項目 (母性看護学, 精神看護学) が除外された．全ての推定方法㧍よび科目の推定にお いて, 収束基準 0.0075 を満たして収束した。 


\section{4. 素点と IRT による評価の比較}

本研究においては，素点に基づいた分析と，IRTに 基づいた分析を行った。これらについて，特に素点に 基づく一次元性が高い分野に関して，IRTの分析にお ける識別力が高い傾向が指摘できる，具体的には，第 1 主成分の寄与率（表 4) の值が大きな分野であるほ ど，IRT における識別力の值（表 5 参照）が大きいと いう傾向が見られた。これは, IRTのモデルに拉いて, IRT に拉ける識別力パラメ夕が因子分析に抢ける因子 負荷に相当する (光永・前川, 2012, p.40) ことと関連 していると考える。このことは，科目単位の第 1 主成 分の值が分野単位に比べて低い值となり，また，科目 単位でIRT による分析を行った場合に, 分野単位で 行った場合よりも識別力の值が低くなったこととも整 合性のある結果といえる。

表 4 の第 1 主成分の寄与率と, 表 5 の分野別に推定 された識別力から科目単位で推定された識別力を引い た差をプロットすると, 表 7 および表 8 で $\theta$ の分野間 相関が高かった看護専門科目に打いては，第 1 主成分 の寄与率が高い分野ほど識別力の差が大きいという傾 向がみられた。しかし, 分野間相関が低かった基礎医 学科目においては, そのような傾向は見られず, 識別 力の差によらず一定の第 1 主成分の值であった。同様 の傾向が，困難度の差をとった場合にも表れた。分野 間相関が高い科目は，その背後に共通の高次因子が仮 定できるので，分野ごとに分析した場合，高次因子の 部分と各分野独自の因子が識別力に反映される。 それ に対し，科目ごとに分析した場合，高次因子の部分の みが識別力推定に反映されるので, 識別力が低くなっ たと考える．分野別に推定することで，困難度の絶対 值が大きな項目に対する識別力が高まることと, 困難 度の極端な值となる項目が少なくなる傾向によって, $\theta$ が極端な值である受験者に対する $\theta$ の推定值がより 中心に集まりやすくなり, 分野間相関が高かった看護 専門科目に打いて, 分析方法の違いによって $\theta$ の推定 值が図 13 から図 16 のように变わったと考える。しか し, 高次因子や独自因子を仮定したモデルを共通項目 デザインに対して適用し，より定量的な分析を行うに は本研究ではデー夕数が少ないといえ, 今後検討すべ きと考える.

$$
\text { 謝辞 }
$$

本研究は日本学術振興会科学研究費補助金（基盤研
究 A）「臨地実習適正化のための看護系大学共用試験 （CBT）実用化と教育カリキュラムの導入」(研究代表 者・柳井晴夫，課題番号 23249089）の助成を受けたも のである。

\section{参 考 文 献}

Arai, S., \& Mayekawa, S. (2011). A comparison of equating methods and linking designs for developing an item pool under item response theory. Behaviormetrika, 38, 1-16.

医療系大学間共用試験実施評価機構 (2012). 臨床実習開 始前の「共用試験」第 10 版.

http://www.cato.umin.jp/e-book/10/index.html

Hanson, B.A., \& Béguin, A.A. (2002). Obtaining a common scale for item response theory item parameters using separate versus concurrent estimation in the common-item equating design. Applied Psychological Measurement, 26, 3-24.

石井秀宗 ·椎名久美子 - 柳井晴夫 (2003). 看護大学生の学 習活動と学習意欲等に関する研究. Quality Nursing, 9(11), 48-62.

石井秀宗 - 椎名久美子 - 前田忠彦 - 柳井晴夫 (2007). 大 学教員に扔ける学生の学力低下意識に影響する諸要 因についての検討. 行動計量学, 34, 67-77.

亀井智子 ·西川浩昭 ·柳井晴夫 (2013). 看護系大学共用 試験用「老年看護学」の問題の開発とメ夕評価一古 典的テスト理論と項目反応理論を用いて一. 日本看 護科学会誌, 33(2), 3-11.

国立大学法人東北大学 (2011). 全国規模の学力調查にお ける重複テスト分冊法適用の試み. 平成 22 年度文部 科学省委託研究「学力調查を活用した専門的課題分 析に関する調查研究」研究成果報告書

Lord, F.M., \& Novick, M.R. (1968). Statistical theories of mental test scores. Reading, MA: AddisonWesley.

前川眞一 (1991). パラメ夕の推定 芝祐順（編）項目反 応理論 基礎と応用. 東京大学出版会, pp.101-102.

光永悠彦・前川眞一 (2013). 多群 IRT モデルにおける簡 素化の評価一水平等化場面のシミュレーヨンを通じ て一. 行動計量学, 40, 29-42.

光永悠彦・前川眞一 (2012). 項目反応理論に基づくテス 卜における項目バンク構築時の等化方法の比較. 日本 テスト学会誌, 8, 31-48.

村木英治 (2011). 項目反応理論 シリーズく行動計量の 科学>8. 朝倉書店

日本テスト学会（編）(2010). 見直そう，テストを支える 基本の技術と教育. 金子書房

Reckace, M.D. (2009). Multidimensional Item Response Theory. New York, NY: Springer.

Reckace, M.D. (1979). Unifactor latent trait models applied to multifactor tests: Results and implications. Journal of Educational and Behavioral Statistics, 4(3), 207-230.

佐伯圭一郎·品川佳満・西川浩昭·柳井晴夫 (2013). 受験者 アンケートによる看護系大学共用試験 $(\mathrm{CBT})$ の評価. 
日本テスト学会第 11 回大会発表論文集, pp.114-115. 佐藤喜一・柴山直 (2011). 下位テストから構成されるテス ト間の等化におけるブートストラップ法を援用した 等化の標準誤差の評価. 日本テスト学会誌, 7, 85-98. 柳井晴夫 · 石井秀宗 (2007). 看護系大学において必要と される教科科目・資質能力・スキルに関する調査研 究. 聖路加看護学会誌, 11(1), 1-9.

柳井晴夫 - 亀井智子 - 松谷美和子 - 奥裕美 - 麻原きよみ 井部俊子.及川郁子 · 大久保暢子. 片岡弥恵子. 萱 間真美 · 鶴若麻理 · 林直子・森明子 ·吉田千文 · 伊藤
圭 - 小口江美子 - 菅田勝也 - 島津明人 - 佐伯圭一郎 · 西川浩昭 (2012). 臨地実習性の質の確保のための看 護系大学共用試験 $(\mathrm{CBT})$ の開発的研究. 聖路加看 護大学紀要, 38, 1-9.

Zimowski, M., Muraki, E., Mislevy, R., \& Bock, R. (2003). BILOG-MG 3 [Computer Program]. Lincolnwood, IL: Scientific Software International.

( 2013 年 7 月 16 日受付， 2013 年 12 月 26 日最終修正） 